International Journal of Instruction e-ISSN: 1308-1470 • www.e-iji.net

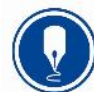

January $2022 \bullet$ Vol.15, No.1

p-ISSN: 1694-609X

pp. 1003-1024

Article submission code 20210402145226

Received: 02/04/2021

Revision: 30/08/2021
Accepted: 22/09/2021

OnlineFirst: 21/12/2021

\title{
Investigating the Influence of Intrinsic Motivation on Behavioral Intention and Actual Use of Technology in Moodle Platforms
}

\section{Arumugam Raman}

Prof., Universiti Utara Malaysia, Malaysia, arumugam@uum.edu.my

\section{Raamani Thannimalai}

Dr., Ministry of Education Malaysia, Malaysia, raamani64@gmail.com

\section{Mohan Rathakrishnan}

Universiti Utara Malaysia, Malaysia, rmohan@uum.edu.my

\section{Siti Noor Ismail}

Universiti Utara Malaysia, Malaysia, siti.noor@uum.edu.my

Web-based course management such as Moodle platforms is gaining popularity in e-learning in higher education. However, there is very little published research that has linked the Self-Determination Theory to technology usage. The purpose of this quantitative study is to examine the influence of UTAUT2 constructs and Intrinsic Motivation (autonomy, competence and relatedness) on behavioural intention and actual use of Moodle in Blended Learning. The questionnaire, based on the adapted Intrinsic Motivation Inventory and the UTAUT2 constructs, was administered to 370 postgraduate students from Universiti Utara Malaysia. PLSSEM was used to analyse the results. Findings of this study revealed that Intrinsic Motivation influenced behavioural intention to use Moodle. All nine latent variables moderately influenced the actual use of technology. The findings of this study have important implications, and further research is suggested to explore the effects of intrinsic motivation on the actual use of learning management systems. Future studies could investigate variables for determining the acceptance of learning management systems such as technological, pedagogical and content knowledge.

Keywords: behavioural intention, motivation, learning management systems, selfdetermination theory, UTAUT2

\section{INTRODUCTION}

$21^{\text {st }}$ century has shifted the learning paradigm to allow us to learn at our own speed, regardless of time or location. Moodle is a web-based open-access platform for creating interactive courses. Web pages, movies, presentations, a quiz, a forum, assignments,

Citation: Raman, A., Thannimalai, R., Rathakrishnan, M., \& Ismail, S. N. (2022). Investigating the influence of intrinsic motivation on behavioral intention and actual use of technology in Moodle platforms. International Journal of Instruction, 15(1), 1003-1024. https://doi.org/10.29333/iji.2022.15157a 
wikis, and debates are among the many resources available. Within the fifty-minute class period, the teacher cannot directly monitor each student while also meeting the demands of the learners. Moodle gives students the ability to access resources on their own time. At present, most of higher education institutions are currently enhancing the nonattendance component of a significant portion of their course material through the establishment full-fledged online courses. There are numerous types of virtual environments available, but they all follow a similar usage methodology and have a similar appearance. They include tools for creating and managing content, as well as synchronous mechanisms - such as real-time chat rooms - and asynchronous mechanisms, such as e-mail and discussion forums. The most widely used virtual platforms are those for commerce, research, and collaboration, which are frequently free. WebCT, Blackboard, Talent LMS, Tovuti LMS, Loop, are among the most widely used commercial systems (elearningindustry.com). We chose to examine Moodle (http://www.moodle.org) as a free research and collaboration Web-based learning system because of its management system for lecturers to create online learning communities.

Digitalisation and implementation of e-learning systems have inspired extensive research on the actual usage of learning management systems (LMS) in Higher Education (HE) (Aldiab et al., 2019; Bahri, Idris, Muis, Arifuddin \& Fikri, 2021). Moodle is web-based course management that has revolutionised teaching and learning as a new normal in education (Aikina \& Bolsunovskaya, 2020; Essel \& Wilson, 2017; Johnson, 2017; Poondej \& Lerdpornkulrat, 2019; Wen \& Yang, 2020). At the time of writing this article, Moodle 3.11 (Modular Object-Oriented Dynamic Learning Environment) has just been released and is readily available in 247 nations with $36,401,209$ courses and 276,000,000 users (Moodle, 2021). This verifies that Moodle is preferred by institutions as well as organisations to deliver holistic student-centred tools and blended environments that augment classroom instruction (Mendieta \& Barkhuizen, 2020; Sabah, 2019; Quinn \& Gray, 2020). Besides Moodle, free and open-source software such as Open edX and Chamilo are the most often used LMSs in HE since they can be deployed on HE servers, which eliminates maintenance expenses (Mpungose \& Khosa, 2020).

Blended learning can be leveraged using Moodle to enhance the use of technology (Tulasi \& Suchitra, 2019). Higher education instructors have progressed from the regular posting of academic records in HTML or PDF on their website to creating training programs or programs that integrate online tutorials with class sessions between learners and training personnel (Moodle, 2019). Distance programs, as well as digital instructional training courses, have been established by sustaining interaction solely between instructors and also learners through information transmission networks. These instructional trainings are important to ensure the large-scale adoption of LMS by instructors based on their level of experience with LMS (Fathema \& Akanda, 2020). Therefore, learning-teaching procedures have been enhanced through the usage of Moodle (Ciudad-Gomez, 2011; Grace \& Caterine, 2019; Kerimbayev, 2019). 
Previous research used the Technology Acceptance Model (TAM) and the Unified Theory of Acceptance and Use of Technology (UTAUT) to investigate students' extrinsic motivation to adopt technology (Butz \& Stupnisky, 2017; Ryan \& Deci, 2000). External factors such as motivation and content quality have been shown to influence usability and perceived ease of use perceptions (Zain, Hanafi, Don, Yaakob \& Sailin, 2019). However, there has been little research on the effects of intrinsic motivation (autonomy, competence, and relatedness), specifically the Self-Determination Theory, on technology usage (Hew \& Kadir, 2016; 2017; Khan et al., 2018). The purpose of this study is to fill a gap in the literature.

The purpose of this study was to investigate the effects of selected variables from the Unified Theory of Acceptance and Use of Technology 2 (UTAUT 2) (performance expectancy, effort expectancy, social influence, facilitating conditions, and habit) (Dakduk et al., 2018; Venkatesh et al., 2012) and Intrinsic Motivation (autonomy, competence, and relatedness) on undergraduates' actual use of Moodle in a blended learning environment. The conceptual framework of this study is depicted in Figure 1. The original UTAUT2 was not used by the researchers because it was applied to a business context and is not important in the teaching and learning process (Yang, 2013). This research is important due to the current norm where almost all teaching and facilitating process conducted online. Furthermore, Moodle is the sole platform used by Universiti Utara Malaysia's undergraduate student to complete their studies. Therefore, this study is expected to reveal positive and negative variables that should be tackled in future.

\section{Literature Review}

As we aware that pandemic Covid 19- changed the ways of learning in higher institutions. Educators still discovering variety of teaching approaches to cater remote learning. They have relied on conducive online learning environment for an effective teaching and learning process. When it comes to designing and sharing course materials with learners, as well as monitoring and analysing progress, Moodle LMS may be extremely useful in the education sector in $21^{\text {st }}$ century learning process. Learners (and their parents) assume that learning will be available online. Moodle site can be accessed via a web browser on a PC, tablet, or other mobile device, or there is a free mobile app for your phone that can offer you structured access to the learning that you need at any time.

Moodle's simple interface, drag-and-drop features, a plethora of plugins and also welldocumented resources, in addition to continuous improvements, make Moodle userfriendly to educators and students. The GNU Public License enables Moodle to be accessed for free as an Open Source Software Program (Nanayakkara, 2017; Liu et al., 2019). All users can utilise Moodle academic programs without any licensing charges while having full access to all advantages of the platform. Furthermore, Moodle is easily accessible from any part of the world as a web based (Asamoah, 2020; Kazanidis et al., 2018). Besides, the Moodle platform is quickly reachable through numerous course management systems (CMS) and internet browsers (Anand \& Eswaran, 2018; Fathi \& Torabi, 2019; Limongelli et al., 2016) 
Furthermore, learners can improve their understanding and their abilities in utilising it. Utilising the Moodle platform consistently throughout an academic year appears to enhance students' cognitive levels compared to those who have utilised this platform before (Martín-Blas \& Serrano-Fernández, 2009). Nonetheless, to carry out e-learning atmospheres such as Moodle, lecturers' acceptance of this innovation is a critical problem (Mafuna \& Wadesango, 2016). The Moodle technology is designed for hybrid learning or blended learning; therefore, the instructor's presence is compulsory to facilitate the teaching and learning process. It is expected standalone platform will be available in future where an entire course could be conducted by a system called Artificial Intelligent tutor.

The UTAUT was formulated by Venkatesh et al. (2003) as a detailed synthesis of previous technology acceptance research with four vital constructs (performance expectancy, effort expectancy, social influence, and facilitating conditions) that affect 'behavioural Intention' to utilise modern technology usage. Past researches specified: i) performance expectancy as the level to which utilising an innovation will certainly give advantages to customers in carrying out specific tasks; ii) effort expectancy is the level of ease concerning customers' use of innovation; iii) social influence is the degree to which customers consider friends and families opinion on how to use modern technology; iv) facilitating conditions describe customers' understandings of the sources as well as assistance offered to carry out actions (Venkatesh et al., 2003).

According to the UTAUT (Venkatesh et al., 2003), performance expectancy, social influence and effort expectancy affect behavioural intention in the usage of innovation, whereas facilitating conditions and the behavioural intention was significant in the use of modern technology. However, the UTAUT2 (Venkatesh et al., 2012) included three more constructs, precisely hedonic motivation, price value (irrelevant in this study), as well as habit.

Nonetheless, in an education and learning setup, emotional aspects need to be considered to gauge the behaviour intent of modern technology usage. To examine the motivational power of the technology, we take a look at motivation research (Deci \& Ryan 2000; 2014; Khan et al., 2017). Researchers identified five major viewpoints that are appropriate in the context of technology: attribute behaviourist, cognitive, selfreliance, self-determination, as well as feeling/emotion (Astleitner, 2000). In this study, we have selected the self-determination viewpoint, with which we examined the results of technology acceptance in education.

Besides, self-determination has currently been effectively used in the context of the modern technology atmosphere in promoting motivation (Butz \& Stupnisky, 2017; Deci \& Vansteenkiste, 2004). Within the Self-Determination Theory, three basic psychological requirements are proposed: competence, autonomy, and social relatedness (Deci \& Ryan, 2002, 2014; Ryan, 1995).

Until now, there is no specific research conducted by integrating Self-Determination Theory tied with the UTAUT model. This research is expected to provide significant insights for future researchers with technology and psychological backgrounds. 


\title{
Competence
}

Causality orientations theory (COT) posits that autonomy will take action according to their interest and values (Vansteenkiste et al., 2010). Cognitive evaluation theory (CET) revealed that incentives and favourable responses positively affect people who view themselves as qualified, skilled, and knowledgeable. The demand for skills describes the sense of effectiveness and success while communicating within their atmosphere (Rigby \& Przybylski, 2009, Vansteenkiste \& Ryan, 2013; White, 1959).

\section{Relatedness}

The requirement for social relatedness describes one's sense of belonging, accessory, as well as for meaningful assimilation with the social atmosphere (Desi \& Vansteenkiste, 2004, Deci \& Ryan, 1985, Baumeister \& Leary, 1995; Deci \& Ryan, 2000). Organismic integration theory (OIT) (Ryan \& Deci, 1985) recommends that contexts that associate with a person's worth or values, objectives, or idea systems are most likely to be internalised and bring about intrinsic inspiration. The Goal contents theory (GCT) differentiates between extrinsic goals such as money, fame and image from inherent goals such as personal growth, close relationships, community contribution and physical health (Ryan et al., 1996)

\begin{abstract}
Autonomy
Although self-determination theory was primarily performed in experimental settings on psychology undergraduates, the vital elements of skills, relatedness, and freedom were viewed as demands for academics to utilise the system to boost teaching and learning. The need for autonomy describes psychological space and accomplishes a specific task (Broeck et al., 2010; Vansteenkiste et al., 2010; Williams et al., 2012). While psychological freedom is chosen based on one's worth and passions (Ryan \& Deci, 1995, Deci \& Ryan, 2012), it also describes acting without external stress or enforcement (Vansteenkiste et al., 2010). As a result, freedom refers both to skilled (a) choice flexibility, which indicates having the ability to pick in between numerous strategies, as well as seasoned (b) task meaningfulness, which suggests that the strategy available adheres with one's very own objectives and also characters.
\end{abstract}

\section{Matching Psychological Needs to Moodle Design Elements}

This study examined online teaching and learning literature in higher education and analysed impact practises. However, due to the large number of studies on Covid-19 under review and word limits, this paper has focused on the most common themes or aspects that were deemed to be the most important for this paper and has left out other important issues (for example, other online tools such as podcasts, MOOCs, gamification, or virtual worlds, and the description of these tools) and mainly focused on Moodle that is currently being used in undergraduate studies.

From Moodle 3.1 onwards, it is feasible to develop and use structures for assessing learners' competencies in the Moodle platform. A learner should demonstrate a skill four times before they achieve a competency: Create four tasks (such as four assignments) to conclude the activity being graded. Establish a passing grade from the 
assignment setting display. For assignments 2, 3 and 4, restrict access until the previous tasks have been completed. In the assignment setups for the last project, broaden 'Course competencies', the required expertise is chosen and established 'Upon activity completion' to 'complete the competency'. The learners submit the task as usual. The educator will mark the submiited task. If all four assignments received a passing grade, the competency is immediately attained.

Independent-learning and student-centred methods can be achieved through learning autonomy. Furthermore, a learner should be given the freedom to acquire and assimilate knowledge without boundaries (Brandl, 2005; Tam, 2000). The standard of rapport and communication between teachers and learners may significantly affect the attitudes and even preconceptions of the learners, which 'block the auto this nomination process' (Chateau \& Zumbihl, 2012). Jing (2016) stated that $82 \%$ of students strongly concur that the Moodle-based system boosts students to use an internet search engine to discover the solution to issues and improve their self-governing understanding capacity. It is expected that $95 \%$ of students are expected to experience online language learning in the future.

The requirement for social relatedness can additionally be influenced by Moodle, where educators and learners can connect. Utilising online forums permits conversation and comments, leading to more students being involved as it is seen as a risk-free atmosphere for those who may not be comfortable talking before their peers. Moodle has the capacity for allowing students to evaluate tasks sent by their peers. Executing such a project method has advantages for both learners and educators: Encourage relationship building between students; motivates a higher order of thinking; the instructor has oversight, produces a learning neighbourhood and provides feedback. Researchers designed a new conceptual framework based on the above syntheses of UTAUT2 and the self-determination theory (Figure 1).

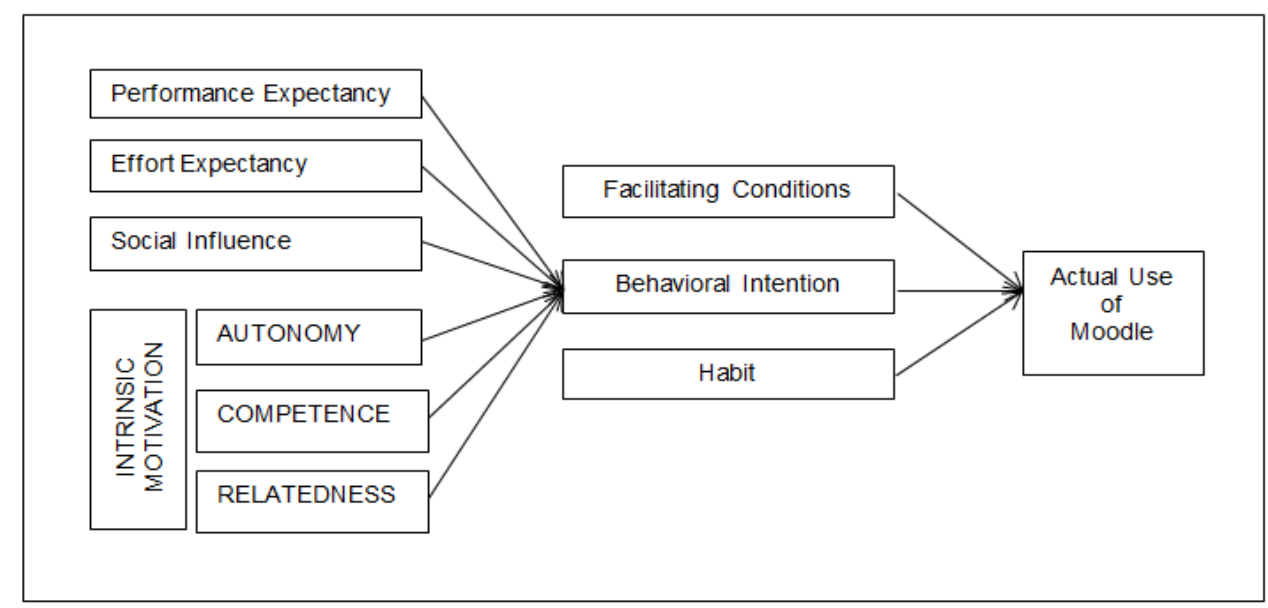

Figure 1

Conceptual framework 
The following hypotheses guide this study: H1: Performance expectancy (PE) positively influences the behavioural intention (BI) to use Moodle; H2: Effort expectancy (EE) positively influences the behavioural intention (BI) to use Moodle; H3: Facilitating conditions (FC) positively influences the actual use (AU) of Moodle; H4: Social influence positively (SI) influences the behavioural intention (BI) to use Moodle; H5: Habit positively (HT) positively influences the actual use (AU) of Moodle; H6: Autonomy positively (AT) influences the behavioural intention (BI) to use Moodle; H7: Competence positively (CT) influences the behavioural intention (BI) to use Moodle; H8: Relatedness positively (RT) influences the behavioural intention (BI) to use Moodle; H9: Behavioral Intention (BI) positively influences the actual use (AU) of Moodle.

\section{METHOD}

This study employed a cross-sectional survey design, and the population was the sample where a convenient sampling method, a non-probability sampling technique, was employed (Tarhini et al., 2014). The convenient sampling method was selected as the sample was readily available and easily accessible (Etikan, Musa \& Alkassim, 2016); the research study was performed across postgraduate schools at Universiti Utara Malaysia (UUM), Malaysia. The Moodle 3.5 platform is available online at all postgraduate colleges. Only blended learning courses were used in this study, unlike other courses which use fully face-to-face methods. The University Teaching and Learning Center (UTLC) of Universiti Utara Malaysia provides information concerning blended learning courses. A course is considered blended if the instructor employs eight resources, three activities, and two assessments. (Figure 2). In this study, students from various postgraduate schools had used Moodle 3.5 in their studies for almost two semesters (6 months). A total of 450 surveys were administrated, from which 370 valid responses were received (Sekaran \& Bougie, 2010), which showed a feedback rate of $82.22 \%$ 


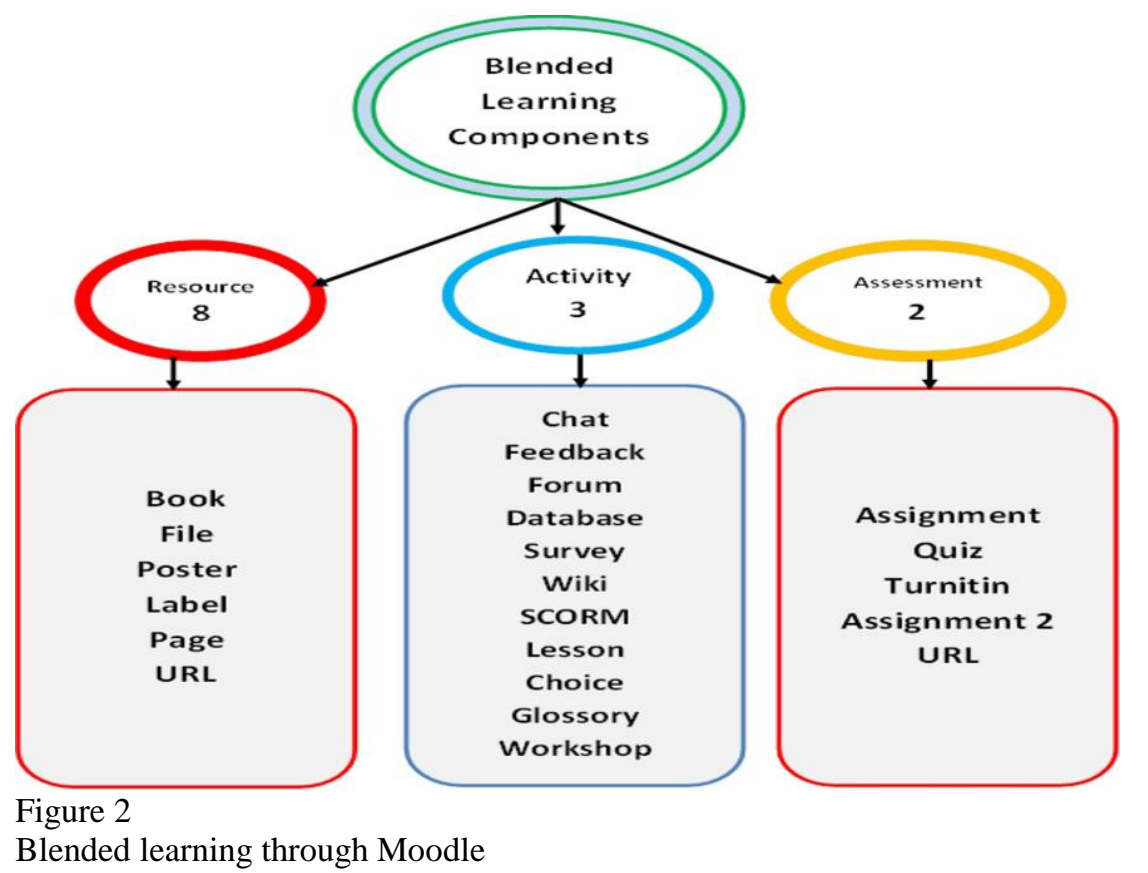

\section{Survey Instrument}

Internet questionnaires (Google Forms) were sent online to all students registered for the first semester of the 2020-2021 academic year. The survey consisted of three parts: The first part collected respondent's particulars, such as school and semester; the second part was designed to collect information regarding the use of Moodle, and the third part collected information concerning the customised UTAUT2 constructs such i) PE, ii) EE, iii) $\mathrm{FC}$, iv) SI, v) HT, vi) $\mathrm{AT}$, vii) $\mathrm{CT}$, viii) $\mathrm{RT}$, ix) $\mathrm{BI}$, and $\mathrm{x}$ ) $\mathrm{AU}$. The variables for the Self-Determination Theory were adapted from the Intrinsic Motivation Inventory (Ryan, 1995; Rigby \& Przybylski, 2009; Ryan \& Deci, 2000) to accommodate the scope of this study. The survey was conducted to investigate students' acceptance of 'online learning' via the Moodle platform. Based on a seven-point Likert scale ranging from " 1 -strongly disagree" to "7-strongly agree", respondents were requested to choose their acceptance level of online learning.

\section{Data Analyses}

Researchers used the Partial least squares-structural equation modelling (PLS-SEM), Smart PLS 3.2.4, to analyse the data (Hair et al., 2017; Venkatesh et al., 2003). Besides, since this study was an exploratory based-research, PLS-SEM was considered a suitable approach (Hair et al., 2017). In terms of the measurement model, Hair et al. (2017) recommended that to establish the convergent validity, scholars need to consider the outer loadings of the manifest variable and the average variance extracted (AVE). 


\section{FINDINGS}

UUM Postgraduate School had approximately 2000 students registered in the 20202021 academic year. A total of 410 postgraduate students responded to the questionnaire. The data cleaning process was conducted to remove outliers and missing data. Finally, 370 valid responses were used in this study to determine the Moodle platform's acceptance level among postgraduate students. Female students dominated the study with a response rate of $58 \%$, whereas the response rate of male students was only $42 \%$. Moreover, $80 \%$ of the students used the Moodle platform for more than two semesters during their postgraduate studies.

\section{Measurement Model Assessment}

The factor loading had to be measured in order to determine the reliability of each manifest variable. A threshold value of equal or greater than 0.7 for each manifest variable loading is considered reliable (Hair et al., 2017). Furthermore, the Cronbach's alpha and composite reliability values need to be equivalent to or higher than 0.7 . It can be observed from Table 1 that all the loadings are acceptable. However, the factor loadings of CT4, AT3, and RT3 were listed below 0.7, and therefore, the three manifest variables were eliminated from the construct's framework. Besides, the average variance extracted (AVE) is defined as the grand mean worth of the squared loadings of the manifest variables connected to the construct and the common measure for establishing the convergent validity. A value of 0.5 or higher for the AVE defines that the construct illuminates over half of the variation of its things (Hair et al., 2017). As shown in Table 1, the composite reliability values and Cronbach's alpha are higher than 0.7 ; in addition, the AVE values are above 0.5 . Therefore, the convergent validity of the constructs is assured. It is suggested that to examine discriminant validity, Heterotrait-Monotrait (HTMT) is used. Discriminant credibility has been confirmed between two reflective constructs if the HTMT value is listed below 0.90 (Henseler et al., 2014). Table 2 shows the Heterotrait-Monotrait proportion (HTMT), and the requirement is met, indicating that the discriminant validity has been established.

\section{Structural Model Assessment}

Figure 3 explains $\mathrm{R}^{2}$, which is the coefficient of determination, is 0.369 for the actual use of Moodle (endogenous latent variable). This means that the nine latent variables (AT, BI, CT, EE, FC, HT, PE, RT, and SI) moderately explained $36.9 \%$ of the variance in the actual use of Moodle. Whereas PE, EE, SI, AT, CT and RT explained $41.8 \%$ of the variance of Behavioral Intention (BI). The inner model suggested that BI has the strongest effect on AU (0.640), followed by FC (0.099) and HT (-0.208). Figure 1 and Table 3 exhibit the path coefficients and p-values for each hypothesis. It can be observed that not all hypotheses were supported.

Hypotheses such as, H2 $(\beta=0.766, \mathrm{p}<0.05), \mathrm{H} 5(\beta=0.766, \mathrm{p}<0.05), \mathrm{H} 6(\beta=0.766$, $\mathrm{p}<0.05)$, H7 $(\beta=0.766, \mathrm{p}<0.05)$, and H9 $(\beta=0.766, \mathrm{p}<0.05)$ are supported and indicate that all five paths are significant between the independent and dependent variables. It means effort expectancy (EE), positively influenced the behavioral intention (BI) to use Moodle; habit (HT) positively influenced the actual use (AU) of Moodle; 
autonomy positively (AT) influenced the behavioral intention (BI) to use Moodle; competence positively (CT) influenced the behavioral intention (BI) to use Moodle; and behavioral intention (BI) positively influenced the actual use (AU) of Moodle.

Table 1

Summary of measurement model

\begin{tabular}{|c|c|c|c|c|c|}
\hline Constructs & Items & Loadings & $\begin{array}{l}\text { Cronbach's } \\
\text { alpha }\end{array}$ & $\begin{array}{l}\text { Composite } \\
\text { reliability }\end{array}$ & $\begin{array}{l}\text { Average Variance } \\
\text { Extracted }\end{array}$ \\
\hline \multirow{4}{*}{$\begin{array}{l}\text { Performance } \\
\text { Expectancy }\end{array}$} & PU1 & 0.780 & \multirow{4}{*}{-0.836} & \multirow{4}{*}{0.89} & 0.669 \\
\hline & PU2 & 0.852 & & & \\
\hline & $\overline{\mathrm{PU} 3}$ & 0.846 & & & \\
\hline & $\overline{\text { PU4 }}$ & 0.792 & & & \\
\hline \multirow{4}{*}{$\begin{array}{l}\text { Effort } \\
\text { Expectancy }\end{array}$} & PE1 & 0.873 & \multirow{4}{*}{-0.886} & \multirow{4}{*}{0.921} & 0.744 \\
\hline & PE2 & 0.867 & & & \\
\hline & PE3 & 0.879 & & & \\
\hline & PE4 & 0.830 & & & \\
\hline \multirow{3}{*}{$\begin{array}{l}\text { Social } \\
\text { Influence }\end{array}$} & SI & 0.890 & \multirow{4}{*}{-0.829} & \multirow{4}{*}{0.896} & 0.743 \\
\hline & $\mathrm{S} 2$ & 0.874 & & & \\
\hline & $\overline{\mathrm{S} 3}$ & 0.819 & & & \\
\hline \multirow{4}{*}{$\begin{array}{l}\text { Facilitating } \\
\text { Conditions }\end{array}$} & $\mathrm{FC} 1$ & 0.791 & & & \\
\hline & FC2 & 0.878 & \multirow{3}{*}{0.899} & \multirow{3}{*}{0.917} & \\
\hline & FC3 & 0.866 & & & 0.735 \\
\hline & FC4 & 0.891 & & & \\
\hline \multirow{4}{*}{ Habit } & HT1 & 0.765 & \multirow{4}{*}{-0.856} & \multirow{4}{*}{0.888} & 0.666 \\
\hline & HT2 & 0.776 & & & \\
\hline & HT3 & 0.844 & & & \\
\hline & HT4 & 0.873 & & & \\
\hline \multirow{3}{*}{ Competency } & CT1 & 0.819 & \multirow{3}{*}{0.763} & \multirow{3}{*}{0.862} & 0.676 \\
\hline & $\mathrm{CT} 2$ & 0.890 & & & \\
\hline & $\overline{\mathrm{CT} 3}$ & 0.752 & & & \\
\hline \multirow{3}{*}{ Autonomy } & AT1 & 0.884 & \multirow{3}{*}{-0.764} & \multirow{3}{*}{0.865} & 0.683 \\
\hline & AT2 & 0.883 & & & \\
\hline & $\overline{\mathrm{AT} 4}$ & 0.699 & & & \\
\hline \multirow{3}{*}{ Relatedness } & RT1 & 0.894 & \multirow{3}{*}{0.892} & \multirow{3}{*}{0.933} & 0.823 \\
\hline & RT2 & 0.938 & & & \\
\hline & RT4 & 0.889 & & & \\
\hline \multirow{3}{*}{$\begin{array}{l}\text { Behavioral } \\
\text { Intention }\end{array}$} & BI1 & 0.809 & \multirow{3}{*}{0.786} & \multirow{3}{*}{0.875} & 0.7 \\
\hline & BI2 & 0.846 & & & \\
\hline & $\mathrm{BI} 3$ & 0.855 & & & \\
\hline \multirow{2}{*}{ Actual Use } & AU1 & 0.859 & \multirow{2}{*}{-0.725} & 0878 & 0.782 \\
\hline & AU2 & 0.909 & & $0.8 / 8$ & \\
\hline
\end{tabular}


Table 2

Heterotrait-Monotrait ratio (HTMT) results

\begin{tabular}{|c|c|c|}
\hline & AT & $\begin{array}{lllllllll}\text { BI } & \text { CT } & \text { EE } & \text { FC } & \text { HT } & \text { PE } & \text { RT } & \text { SI } & \text { AU }\end{array}$ \\
\hline \multicolumn{3}{|l|}{$\overline{\mathrm{AT}}$} \\
\hline$\underline{\mathrm{BI}}$ & 0.714 & \\
\hline CT & 0.590 & 0.624 \\
\hline$\overline{\mathrm{EE}}$ & 0.563 & 0.4800 .206 \\
\hline$\overline{\mathrm{FC}}$ & 0.408 & 0.2430 .1690 .503 \\
\hline HT & 0.592 & 0.4190 .2670 .5080 .832 \\
\hline PE & 0.613 & 0.4630 .3490 .7050 .4460 .439 \\
\hline$\overline{\mathrm{RT}}$ & 0.505 & 0.4340 .4600 .3460 .1740 .2250 .409 \\
\hline$\overline{\text { SI }}$ & 0.557 & 0.3980 .2520 .7770 .6760 .6160 .7980 .341 \\
\hline$\overline{\mathrm{AU}}$ & 0.487 & 0.7690 .4510 .3040 .1060 .1180 .3030 .3680 .206 \\
\hline
\end{tabular}

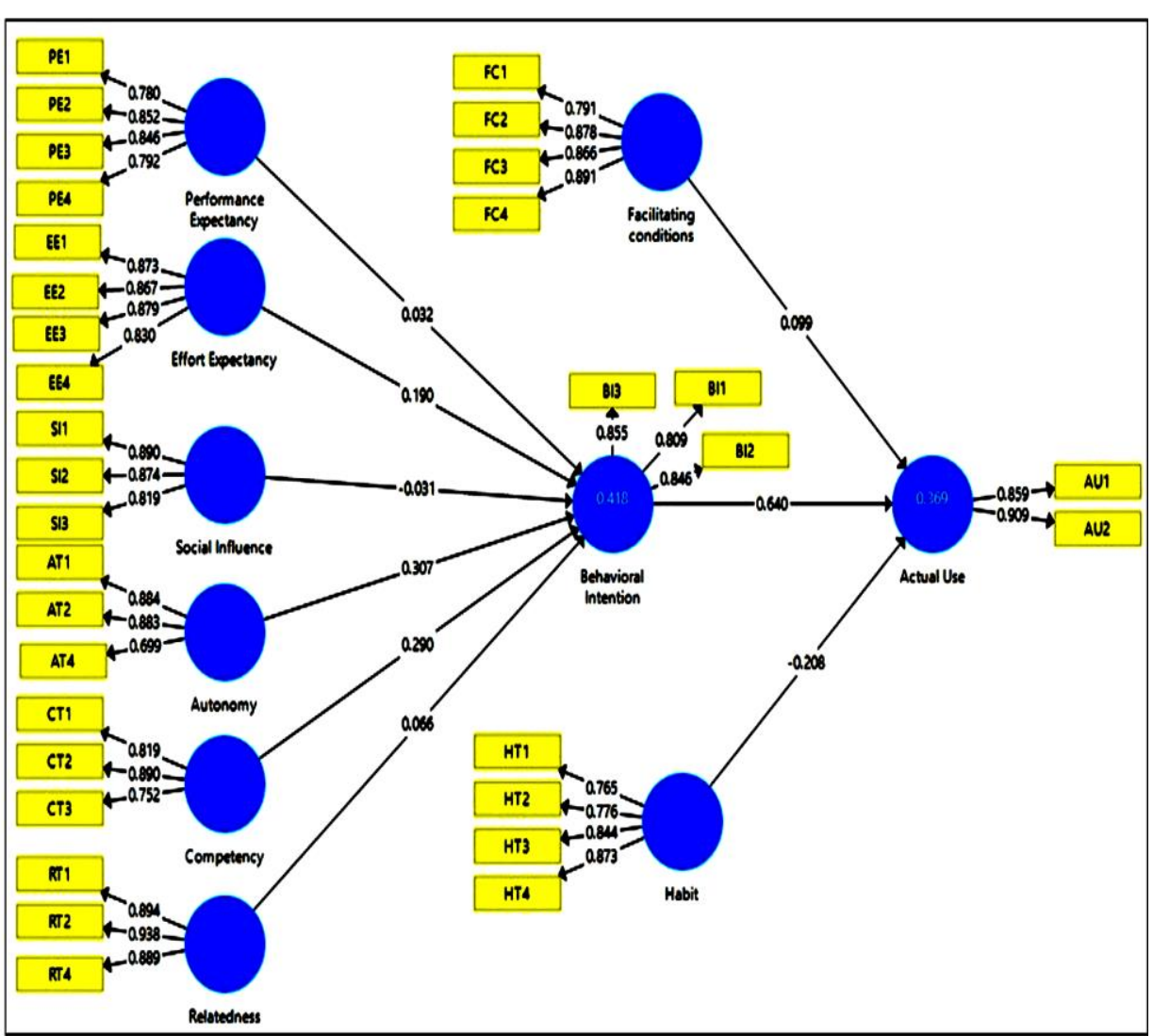

Figure 3

The path analysis results 
Table 3

Hypotheses test results

\begin{tabular}{lllll}
\hline Hypothesis & Path & Path Coefficient & $p$-value & Remarks \\
\hline H1 & PE->BI & 0.032 & 0.633 & Not Supported \\
\hline H2 & EE-> BI & 0.190 & 0.000 & Supported \\
\hline H3 & FC->AU & 0.099 & 0.261 & Not Supported \\
\hline H4 & SI->BI & -0.031 & 0.621 & Not Supported \\
\hline H5 & HT->AU & -0.208 & 0.017 & Supported \\
\hline H6 & AT->BI & 0.307 & 0.000 & Supported \\
\hline H7 & CT->BI & 0.290 & 0.000 & Supported \\
\hline H8 & RT->BI & 0.066 & 0.200 & Not Supported \\
\hline H9 & BI->AU & 0.640 & 0.000 & Supported \\
\hline
\end{tabular}

Thus, it can be concluded that effort expectancy (EE), autonomy (AT), and competence (CT) enhanced the behavioural intention (BI) to use Moodle in this study. Furthermore, habit (HT) contributed towards the actual use (AU) of Moodle; however, facilitating conditions (FC) did not influence the actual use (AU) of Moodle. Decision-makers and future researchers should consider PE, SI and BI constructs before including them in studies related to education atmospheres.

\section{DISCUSSION}

This study confirmed the factors affecting Moodle assisted classroom acceptance by adopting the UTAUT2 amongst postgraduate students at UUM. The PLS-SEM approach was used to assess the measurement and structural models. The outcomes revealed that not all the factors were significantly effective in terms of both the behavioural intention and actual usage of Moodle. The emphasis was placed on effort expectancy and habit as crucial features of Moodle use behaviour. However, there were a few interesting findings in this study. Performance expectancy and social influence did not contribute towards behavioural intention to use Moodle in students learning process. This finding contradicts Raman and Don (2013); Samsudeen and Mohamed (2019), who opined a positive relationship between performance expectancy, effort expectancy and social influence with behavioural intention and the use of LMS among postgraduate students. The contribution of this study has been to confirm that students do not perceive that Moodle platforms would assist them in carrying out everyday lessons; improve their comprehension of studies; assist them in completing the assignment or help them improve their academic performance. Moreover, the findings establish that students did not place importance on the opinion of influential people when using Moodle.

This study aligned with a study conducted in France (Lebeaux et al, 2021) that found that using Moodle for blended learning on Infectious Diseases and Microbiology improved student satisfaction and attendance (81.9 percent vs. 73.8 percent, $\mathrm{P}=0.01)$. Garca-Murillo, Novoa-Hernández, and Rodrguez (2020) conducted a meta-analysis on the level of global technological satisfaction that Moodle users have in the context of Higher Education. It also revealed that, despite advances in educational technology, 
some lecturers and students are resistant to change because they are influenced by factors such as technological satisfaction, which determines users' intention to use the LMS. These findings are consistent with the findings of (Fenu, Marras, \& Meles, 2017; Sahid, Santosa, Ferdiana, \& Lukito, 2016), who evaluated Moodle from both technical and expert perspectives. Despite this, some studies, such as (Stewart, Briton, Gismondi, Heller, Kennepohl, McGreal, \& Nelson, 2007) and (Stantchev, Colomo-Palacios, SotoAcosta, \& Misra, 2014), found low levels of satisfaction. In the first case, the authors compared Moodle to two LMSs and relied on the feedback of 17 users. The small sample size used, in our opinion, influenced the reported results. Stantchev et al. (2014) also conducted a comparison, but this time Moodle was pitted against cloud file hosting services (CFHS), which were compared using TAM rather than UTAUT. The authors discovered that CFHS had a higher perceived usefulness and attitude toward using it than Moodle. Despite the fact that the sample size in this study was over 100 users, we believe that such a comparison had a significant impact on the results. LMSs serve a different, broader purpose than cloud file hosting services. They are ubiquitous in today's mobile devices, allowing for file sharing and collaboration among users in a variety of contexts. As a result, it is reasonable to anticipate a preference for this type of service over Moodle, which is primarily intended to improve learning.

Past researches endorsed that performance expectancy had positive influences on behavioural intention in the use of technology (Dakduk et al., 2018; Raman \& Don, 2013; Samsudeen \& Mohamed, 2019; Tam, 2000; Venkatesh et al., 2012; Zwain, 2019) in both UTAUT and UTAUT2 models. Moreover, the performance expectancy variable represented perceived usefulness (Davis et al., 1989) and relative advantage (Moore \& Benbasat, 1991) constructs from previous research on technology acceptance. However, this study contradicted past findings as performance expectancy did not support behavioural intention (Table 3) as there are many reasons that could have caused this phenomenon. Initially, this study defined performance expectancy as the level to which utilising an innovation will be advantageous to students in carrying out specific tasks. The data collected from this study was conducted after UUM adopted a new version of Moodle, which is Moodle 3.5. Many new features were incorporated in the latest Moodle 3.5, and these changes required prior specialised training to be given to students. As a result, many students were not fully accustomed to the new layout and design. These factors may have affected performance expectancy and, consequently, behavioural intention.

Moreover, this study also found that the influence of facilitating conditions was insignificant on the actual use of Moodle. This is also contradicting to Ain et al. (2016), Raman and Don (2013); Samsudeen and Mohamed (2019); Zwain (2019); who suggested that facilitating conditions is a significant predictor of the actual use of LMS.

Conversely, this study showed that habit enhanced the actual use of Moodle. This outcome is aligned to Raman and Don (2013) and Zwain (2019), who reported that habit has positive effects on the actual use of LMS. However, it contradicted the findings of Dakduk et al. (2019), who posited that habit does not predict the intention to adopt blended learning. 
Another new finding of this study that could add to the body of knowledge was that social influence did not leverage the behavioural intention to use Moodle. Although this is aligned with Khan et al., (2017) studies, it contradicted many other findings related to technology acceptance (Ain et al., 2016; Raman \& Lateh, 2015; and Samsudeen \& Mohamed, 2019; Venkatesh et al., 2003). This could have occurred because the use of Moodle was not compulsory in higher education, and instructors could not penalise students if they did not log into the Moodle platform.

The measurement model (Table 3) also displayed that facilitating conditions did not positively influence the actual use of the Moodle platform. This finding does not support Sulaiman and Mohamed (2019); however, facilitating conditions proved to significantly positively affect behavioural intention in the consumer context in the UTAUT 2 model (Venkatesh et al., 2012). Previous studies on the social influence adoption also confirmed that the availability of various facilitating conditions might significantly influence student's intention to adopt or reject learning (Raman \& Don, 2013; Yang, 2012). Moodle provides excellent space to develop thinking skills among students such as discussion board, quick messaging, contact form, and quality assessments \& feedback. Using a well-structured project, discussion or essay question, you can quickly determine how well students know the content and whether or not they have developed the skills to synthesise course material and apply it to new situations.

The researchers found that two intrinsic motivation factors, i.e. autonomy and competency, exhibited positive influence on behavioural intention to use Moodle (Butz \& Stupnisky, 2017; Hui et al., 2019; Narendran, 2018; Zainuddin \& Perera, 2017). These two factors were integrated into the UTAUT2 model to examine their influence on the actual use of Moodle. The autonomy and competency constructs proved that psychological factors must be considered to measure technology acceptance in educational settings. However, contradicting previous research findings (Zainuddin \& Pereira, 2017; Enfeld, 2013; Kim et al., 2014; Zainuddin \& Attaran, 2015), relatedness did not positively influence behavioural intention to use Moodle.

This study is aligned with other past researchers in terms of habit and behavioural intention as both of these constructs showed positive influence towards actual use of Moodle (Khan et al., 2017; Samsudeen \& Mohamed, 2019; Venkatesh et al., 2012.) However, the data analysis found that habit had less effect on the actual use of Moodle compared to behavioural intention because Moodle is an educational platform and not a game-based system; thus, addiction is irrelevant in this study. However, Moodle psychologically has a significant positive effect on student's behaviour. This has been proven from the hypothesis testing, as shown in Table 3.

This research's theoretical and practical contribution to the existing literature on technology acceptance is the inclusion of intrinsic motivation constructs (autonomy, competence and relatedness) to the UTAUT2 model. An important implication of this study is that both constructs of the UTAUT2 and the Self-Determination Theory should be considered when determining the use of Moodle in higher education as they have significant impacts on behavioural intentions. To date, researchers studying SDT in education have primarily concentrated on student autonomy or the use of internet-based 
technologies. However, the application of SDT in learning management systems is novel in this study, providing educators with information on how to maximise the motivational potential of Moodle in higher education. This study is crucial and relevant, especially now during the Covid-19 pandemic when students have to be highly motivated to engage in online learning through various web management systems.

The present investigation was limited by a few issues regarding the Moodle platform. Many postgraduate schools at UUM received complaints during the transition period of Moodle 3.5 regarding technical problems with the platform such as 'server down, 'no connection', 'login in' and 'log out', and 'wrong contents' during teaching and learning. These problems may have affected student's responses during data collection. Therefore, we were unable to conclude if the effect of the facilitating conditions was significant in the context of this study. A task-force team (24/7) must be formed to tackle and fix the technical problem immediately.

\section{RECOMMENDATIONS}

Further research needs to be undertaken to identify other variables for determining the acceptance of learning management systems amongst students, such as content, technological and pedagogical knowledge. These new variables may reveal the ideal model of technology acceptance among students in higher education. These findings suggest that Moodle developers upgrade the features of Moodle and incorporate communication tools to enhance collaborative tasks for students, teamwork and group acceptance.

\section{CONCLUSION}

In short, Moodle technology for fully online classroom or blended classroom is mandatory for instructors to make the teaching and learning process more manageable. In future, an entire course can be carried on by a system known as an artificial intelligent tutor, and its expected standalone platform will be available. Furthermore, the outcomes of this study will give foresight to higher educations to implement learning management systems effectively and empower student learning to prepare them for digitalisation in the $21^{\text {st }}$ century. We recommend using multiple online learning supported platform during pandemic Covid -19, such as Edmodo, Webex, Google Meet, Google Classroom, Zoom, etc., to enhance the teaching and facilitation process. Depending on a sole online learning platform will lead to inability to accommodate student's cognitive, affective and psychomotor requirements.

Using ICT in higher education has its drawbacks. This study provided empirical data on the factors influencing undergraduates' Moodle use outcomes in a online learning context. The investigation focused on usability factors and relevant external support. We demonstrated that usability factors (i.e., effort expectancy, habit, student autonomy, and student competency) are important antecedents to improving students' Moodle use outcomes in a online setting. This research has added to the growing body of work, particularly that focusing on use and learning outcomes. The attention of practitioners is also drawn to key issues in the discourse. 


\section{ACKNOWLEDGEMENTS}

We acknowledge the anonymous reviewers for their constructive suggestions and careful editing help.

\section{DISCLOSURE STATEMENT}

No potential conflict of interest was reported by the authors.

\section{FUNDING}

The author(s) received no financial support for the research, authorship, and/or publication of this article.

\section{REFERENCES}

Aikina, T. Y., \& Bolsunovskaya, L. M. (2020). Moodle-based learning: Motivating and demotivating factors. International Journal of Emerging Technologies in Learning (iJET), 15(02), 239-248.

Ain, N., Kaur, K., \& Waheed, M. (2016). The influence of learning value on learning management system use: An extension of UTAUT2. Information Development, 32(5), 1306-1321.

Aldiab, A., Chowdhury, H., Kootsookos, A., Alam, F., \& Allhibi, H. (2019). Utilisation

of Learning Management Systems (LMSs) in higher education system: A case review

for Saudi Arabia. Energy Procedia, 160, 731-737. doi: 10.1016/j.egypro.2019.02.186.

Anand, A., \& Eswaran, S. (2018). Case study: Moodle approach to learning and content management system (LCMS). International Journal of Computer Sciences and Engineering, 6(7), 1147-1152.

Asamoah, M. K. (2020). Reflections and refractions on Sakai/Moodle learning management system in developing countries: A case of Ghanaian universities' demand and supply perspective analyses. African Journal of Science, Technology, Innovation and Development, 12(2), 243-259.

Astleitner, H. (2000). Designing emotionally sound instruction: The FEASPapproach. Instructional Science, 28, 169-198, https://doi: 10.1023/A:1003893915778

Baumeister, R. F., \& Leary, M. R. (1995). The need to belong: Desire for interpersonal attachments as a fundamental human motivation. Psychological Bulletin, 117(3), 497529. https://doi: 10.1037//0033-2909.117.3.497

Bahri, A., Idris, I. S., Muis, H., Arifuddin, M., \& Fikri, M., J., N. (2021). Blended Learning Integrated with Innovative Learning Strategy to Improve Self-Regulated Learning.International Journal of Instruction, 14(1), 779-794. https://doi.org/10.29333/iji.2021.14147a

Broeck, A., Vansteenkiste, M., Witte, H., Soenens, B., \& Lens, W. (2010). Capturing autonomy, competence, and relatedness at work: Construction and initial validation of 
the work-related basic need satisfaction scale. Journal of Occupational and Organizational Psychology, 83(4), 981-1002. https://doi: 10.1348/096317909x481382

Butz, N. T., \& Stupnisky, R. H. (2017). Improving student relatedness through an online discussion intervention: The application of self-determination theory in synchronous hybrid programs. Computers \& Education, 114, 117-138.

Chateau, A. \& Zumbihl, H. (2012). Learners perceptions of the pedagogical relations in a flexible language learning system, Computer Assisted Language Learning, 25(2), 165-179.

Ciudad-Gómez Adelaida. (2011). Teaching innovation and use of the ICT in the teaching-learning process within the new framework of the EHEA, by means of moodle platform. American Journal of Business Education (AJBE), 3(13). https://doi: 10.19030/ajbe.v3i13.972

Davis, F. D., Bagozzi, R. P., \& Warshaw, P. R. (1989). User acceptance of computer technology: A comparison of two theoretical models. Management Science, 35(8), 982 1003. https://doi: 10.1287/mnsc.35.8.982

Dakduk, S., Santalla-Banderali, Z., \& van der Woude, D. (2018). Acceptance of blended learning in executive education. SAGE Open, 8(3), 2158244018800647.

Deci, E. \& Vansteenkiste, M. (2004). Self-determination theory and basic need satisfaction: Understanding human development in positive psychology. Ricerche di Psicologia, 27(1), 23-40.

Deci, E. L., \& Ryan, R. M. (2002). Overview of self-determination theory: An organismic dialectical perspective. Handbook of self-determination research, 3-33. in Handbook of self-determination research, Ryan, R. and Deci. E.L, Ed. Rochester: University of Rochester Press.

Deci E. L., \& Ryan, R. M. (2000). The "what" and "why" of goal pursuits: Human needs and the self-determination of behavior, Psychological Inquiry, 11, (4), 227-268. https://doi. 10.1207/S15327965PLI1104_01

Deci, E. L., \& Ryan, R. M. (2014). Intrinsic motivation and self-determination in human behavior. New York: Springer Science Business Media.

Deci, E. L., \& Ryan, R. M. (2012). Motivation, personality, and development within embedded social contexts: An overview of self-determination theory. Oxford Handbooks Online. https://doi: 10.1093/oxfordhb/9780195399820.013.0006

Essel, D. D., \& Wilson, O. A. (2017). Factors affecting university students' use of Moodle: An empirical study based on TAM. International Journal of Information and Communication Technology Education (IJICTE), 13(1), 14-26.

Etikan, I., Musa, S. A., \& Alkassim, N. S. (2016). Comparison of convenience sampling and purposive sampling. American J. of Theoretical and Applied Statistics, 5(1), 1-4. 
Fathema, N., \& Akanda, M. H. (2020). Effects of instructors' academic disciplines and prior experience with learning management systems: A study about the use of Canvas. Australasian Journal of Educational Technology,36(4), 113-125. https://doi.org/10.14742/ajet.5660

Fathi, J., \& Torabi, S. (2019). The contribution of a course management system (CMS)supported instruction to developing grammar performance: A case of iranian EFL learners. CALL EJ, 20(2), 89-98.

Fenu, G., Marras, M., \& Meles, M. (2017). A learning analytics tool for usability assessment in moodle environments. Journal of e-Learning and Knowledge Society, 13(3).

García-Murillo, G., Novoa-Hernández, P., \& Rodríguez, R. S. (2020). Technological Satisfaction About Moodle in Higher Education-A Meta-Analysis. IEEE Revista Iberoamericana de Tecnologias del Aprendizaje, 15(4), 281-290.

Grace, D., \& Caterine, W. (2019). Using MOODLE as blended learning for assessment in writing class. EDUCAFL: Journal of Education of English as a Foreign Language, 2(1), 26-31.

Hair, J. F., Hult, G. T. M., Ringle, C. M., \& Sarstedt, M. (2017). A primer on partial least squares- structural equation modeling (PLS-SEM). Los Angeles: Sage.

Henseler, J., Ringle, C. M., \& Sarstedt, M. (2014). A new criterion for assessing discriminant validity in variance-based structural equation modeling. Journal of the Academy of Marketing Science, 43(1), 115-135. https://doi: 10.1007/s11747-014-04038.

Hew, T. S., \& Kadir, S. L. S. A. (2016). Predicting the acceptance of cloud-based virtual learning environment: the roles of self-determination and channel expansion theory. Telematics and Informatics, 33(4), 990-1013.

Hew, T. S., \& Syed A. Kadir, S. L. (2017). Applying channel expansion and selfdetermination theory in predicting use behaviour of cloud-based VLE. Behaviour \& Information Technology, 36(9), 875-896.

Hui, Y. K., Li, C., \& Qian, S. (2019). Learning engagement via promoting situational interest in a blended learning environment. Journal of Computing in Higher Education, 31(2), 408-425.

Liu, D. Y. T., Atif, A., Froissard, J. C., \& Richards, D. (2019, January). An enhanced learning analytics plugin for Moodle: Student engagement and personalised intervention. In ASCILITE 2015-Australasian Society for Computers in Learning and Tertiary Education, Conference Proceedings.

Johnson, M. (2017). Library instruction for first year students using a CMS meta-course: Scalable and customisable!. Journal of Library \& Information Services in Distance Learning, 11(1-2), 262-268. 
Jing, M. A. (2016). The application of Moodle-based platform in college English learning. Sino-US English Teaching, 13(5), 332-337.

Kazanidis, I., Pellas, N., Fotaris, P., \& Tsinakos, A. (2018). Facebook and Moodle integration into instructional media design courses: A comparative analysis of students' learning experiences using the community of inquiry (CoI) model. International Journal of Human-Computer Interaction, 34(10), 932-942.

Kerimbayev, N., Nurym, N., Akramova, A., \& Abdykarimova, S. (2019). Virtual educational environment: Interactive communication using LMS Moodle. Education and Information Technologies, 1-18.

Khan, I. U., Hameed, Z., Yu, Y., Islam, T., Sheikh, Z., \& Khan, S. U. (2018). Predicting the acceptance of MOOCs in a developing country: Application of task-technology fit model, social motivation, and self-determination theory. Telematics and Informatics, 35(4), 964-978.

Kim, M. K., S. M. Kim, O. Khera, \& J. Getman. (2014). The experience of three flipped classrooms in an urban university: An exploration of design principles. The Internet and Higher Education, 22, 37-50.

Limongelli, C., Lombardi, M., Marani, A., Sciarrone, F., \& Temperini, M. (2016). A recommendation module to help teachers build courses through the Moodle learning management system. New Review of Hypermedia and Multimedia, 22(1-2), 58-82.

Lebeaux, D., Jablon, E., Flahault, C., Lanternier, F., Viard, J. P., Pacé, B., ... \& Lemogne, C. (2021). Introducing an Open-Source Course Management System (Moodle) for Blended learning on infectious diseases and microbiology: A pre-post observational study. Infectious Diseases Now. https://doi.org/10.1016/j.idnow.2020.11.002.

Mafuna, L., \& Wadesango, N. (2016). Exploring lecturers' acceptance level of learning management system (LMS) at applying the extended technology acceptance model (TAM). Journal of Social Sciences, 48(1-2), 63-70. https://doi: 10.1080/09718923.2016.11893571

Martín-Blas, T., \& Serrano-Fernández, A. (2009). The role of new technologies in the learning process: Moodle as a teaching tool in Physics. Computers \& Education, 52(1), 35-44. https://doi: 10.1016/j.compedu.20

Mendieta, J., \& Barkhuizen, G. (2020). Blended language learning in the Colombian context: A narrative inquiry of teacher ownership of curriculum change. Computer Assisted Language Learning, 33(3), 176-196.

Moodle. (2021). https://moodle.net/stats/

Moodle. (2019). https://docs.moodle.org/37/en/About_Moodle 
Moore, G. C., \& Benbasat, I. (1991). Development of an instrument to measure the perceptions of adopting an information technology innovation. Information Systems Research, 2(3), 192-222. https://doi: 10.1287/isre.2.3.192

Mpungose, C. B., \& Khoza, S. B. (2020). Postgraduate Students' Experiences on the Use of Moodle and Canvas Learning Management System. Technology, Knowledge and Learning, 1-16. https://doi:10.1007/s10758-020-09475-1

Nanayakkara, S. (2017). Impact of free and open-source software paradigm for environmental sustainability-case study in higher education sector. International Journal of Research in Electronics and Computer Engineering, 5(4), 174-188.

Narendran, R., Almeida, S., Coombes, R., Hardie, G., Quintana-Smark, E., Zaher, N., ... \& Stevenson, B. (2018). The role of self-determination theory in developing curriculum for flipped classroom learning: A case study of first-year business undergraduate course. Journal of University Teaching and Learning Practice, 15(5), 6.

Poondej, C., \& Lerdpornkulrat, T. (2019). Gamification in e-Learning: A Moodle Implementation and Its Effect on Student Engagement and Performance. Interactive Technology and Smart Education, 17(1), 56-66.

Quinn, R. J., \& Gray, G. (2020). Prediction of student academic performance using Moodle data from a further education setting. Irish Journal of Technology Enhanced Learning, 5(1).

Raman, A., \& Lateh, H. (2015). Using facebook as a collaborative and communicative tool. Mediterranean Journal of Social Sciences. https://doi:10.5901/mjss.2015.v6n1s1p286

Raman, A., \& Don, Y. (2013). Pre-service teachers' acceptance of learning management software: An application of the UTAUT2 model. International Education Studies, 6(7). https://doi: 10.5539/ies.v6n7p157

Rigby, C. S., \& Przybylski, A. K. (2009). Virtual worlds and the learner hero: How today's video games can inform tomorrow's digital learning environments. Theory and Research in Education, 7(2), 214-223.

Ryan, R. M. (1995). Psychological needs and the facilitation of integrative processes. Journal of Personality,63(3), 397-427. https://doi: 10.1111/j.14676494.1995.tb00501.x

Ryan, R.M. \& E.L. Deci. (2000). Self-determination theory and the facilitation of intrinsic motivation, social development, and well-being, American Psychologist, 5, 6878. http://dx.doi.org/10.1037/0003-066X.55.1.68

Ryan, R., Sheldon, K., Kasser, T., \& Deci, E. (1996). All goals are not created equal: An organismic perspective on the nature of goals and their regulation. In P. M. Gollwitzer \& J. A. Bargh (Eds.). The psychology of action: Linking cognition and motivation to behavior (p. 7-26). New York: Guilford Press 
Sabah, N. M. (2019). Motivation factors and barriers to the continuous use of blended learning approach using Moodle: Students' perceptions and individual differences. Behaviour \& Information Technology, 1-24.

Sekaran, U. \& Bougie, R. (2010). Research Methods for Business: A Skill Building Approach. Wiley: India.

Sahid, D. S. S., Santosa, P. I., Ferdiana, R., \& Lukito, E. N. (2016, August). Evaluation and measurement of Learning Management System based on user experience. In 2016 6th International Annual Engineering Seminar (InAES) (pp. 72-77). IEEE.

Samsudeen, S., \& Mohamed, R. (2019). University students' intention to use e-learning systems. Interactive Technology and Smart Education, 16(3), 219-238. https://doi.org/10.1108/itse-11-2018-0092.

Stantchev, V., Colomo-Palacios, R., Soto-Acosta, P., \& Misra, S. (2014). Learning management systems and cloud file hosting services: A study on students' acceptance. Computers in Human Behavior, 31, 612-619.

Stewart, B., Briton, D., Gismondi, M., Heller, B., Kennepohl, D., McGreal, R., \& Nelson, C. (2007). Choosing Moodle: An evaluation of learning management systems at Athabasca University. International Journal of Distance Education Technologies (IJDET), 5(3), 1-7.

Tam, M. (2000). Constructivism, instructional design, and technology: Implications for transforming distance learning", Educational Technology \& Society, 3 (2).

Tarhini, A., Hone, K. and Liu, X. (2014). The effects of individual differences on elearning users' behaviour in developing countries: A structural equation model. Computers in Human Behaviour, 41, 153-163.

Tulasi, B., \& Suchitra, R. (2019). Personalised learning environment in higher education through big data and blended learning analytics. International Journal of Recent Technology and Engineering, 8(3), 6236-6239. https://doi: 10.35940/ijrte.c5778.098319

Vansteenkiste, M., \& Ryan, R. M. (2013). On psychological growth and vulnerability: Basic psychological need satisfaction and need frustration as a unifying principle. Journal of Psychotherapy Integration,23(3), 263-280. https://doi: $10.1037 / \mathrm{a} 0032359$

Vansteenkiste, M., Niemiec, C. P., \& Soenens, B. (2010). The development of the five mini-theories of self-determination theory: an historical overview, emerging trends, and future directions. Advances in Motivation and Achievement The Decade Ahead: Theoretical Perspectives on Motivation and Achievement, 105-165. https://doi: 10.1108/s0749-7423(2010)000016a007

Vansteenkiste, M., Williams, G. C., \& Resnicow, K. (2012). Toward systematic integration between self-determination theory and motivational interviewing as examples of top-down and bottom-up intervention development: autonomy or volition as 
a fundamental theoretical principle. International Journal of Behavioral Nutrition and Physical Activity, 9(1), 23. https://doi: 10.1186/1479-5868-9-23

Venkatesh, Morris, Davis, \& Davis. (2003). User acceptance of information technology: Toward a unified view. MIS Quarterly, 27(3), 425. https://doi: 10.2307/30036540

Venkatesh, Thong, \& Xu. (2012). Consumer acceptance and use of information technology: Extending the unified theory of acceptance and use of technology. MIS Quarterly, 36(1), 157. https://doi: 10.2307/41410412

Wen, J., \& Yang, F. (2020). Use of Moodle in college English language teaching (reading and listening) in China: A narrative review of the literature. International Journal of Information and Education Technology, 10(6).

White, R. W. (1959). Motivation reconsidered: The concept of competence. Perspectives in Psychology, 33-59. https://doi: 10.1037/14156-005

Yang, K. (2012). Consumer technology traits in determining mobile shopping adoption: An application of the extended theory of planned behavior. Journal of Retailing and Consumer Services, 19(5), 484-491. https://doi: 10.1016/j.jretconser.2012.06.003

Yang, S. (2013). Understanding undergraduate students' adoption of mobile learning model: A perspective of the extended UTAUT2. Journal of Convergence Information Technology, 8(10), 969-979. https://doi: 10.4156/jcit.vol8.issue10.118

Zain, F. M., Hanafi, E., Don, Y., Yaakob, M. F. M., \& Sailin, S. N. (2019). Investigating Student's Acceptance of an EDMONDO Content Management System. International Journal of Instruction, 12(4), 1-16. https://doi:10.29333/iji.2019.1241a

Zainuddin, Z., and M. Attaran. (2015). Malaysian students' perceptions of flipped classroom: A case study. Innovations in Education and Teaching International 53 (6), 660-670.

Zainuddin, Z., \& Perera, C. J. (2017). Exploring students' competence, autonomy and relatedness in the flipped classroom pedagogical model. Journal of Further and Higher Education, 43(1), 115-126.

Zwain, A. (2019). Technological innovativeness and information quality as neoteric predictors of users' acceptance of learning management system. Interactive Technology And Smart Education, 16(3), 239-254. https://doi: 10.1108/itse-09-2018-0065 